\title{
Humus forms in two secondary semi-evergreen
}

\section{tropical forests}

G. LORANGER ${ }^{a}$, J.F. PONGE ${ }^{b} \&$ P. LAVELLE ${ }^{a}$

a UMR BIOSOL, IRD-Université Paris VI, 32 Avenue Henri Varagnat, 93143 Bondy Cedex, France

b Muséum National d'Histoire Naturelle, Laboratoire d'Écologie Générale, 4 Avenue du Petit Château, 91800 Brunoy, France.

Correspondence: J.F.Ponge, E-mail: Jean-Francois.Ponge@wanadoo.fr

Short title: Tropical humus forms 


\section{Summary}

The dynamics and function of humus forms in tropical forests are still poorly understood. Humus profiles in two secondary semi-evergreen woodlands in Guadeloupe (French West Indies) were analysed micromorphologically. The humus forms are described under the canopy of five dominant tree species at two sites: under Pisonia subcordata and Bursera simaruba in a secondary forest on a Leptosol (Rendzina), and under Swietenia macrophylla, Tabebuia heterophylla and B. simaruba in a plantation on a calcareous Vertisol.

In the secondary forest, two distinct humus forms were observed. A calcareous Amphimull, characterized by an $\mathrm{OH}$ horizon comprising the faecal pellets of millipedes, is formed under the canopy of $P$. subcordata, which produces a litter that is rich in nitrogen. A Dysmull with a thick root mat ( $\mathrm{OF}_{\mathrm{Rh}}$ horizon) develops under the canopy of $B$. simaruba, which produces a litter rich in lignin and phenol that is consumed slowly by soil fauna. In the plantation on the Vertisol, the activity of the endoanecic earthworm Polypheretima elongata has led to the rapid disappearance of litter and the mixing of organic and mineral material. The humus form is an Eumull and is similar under all three tree species present.

\section{Introduction}

Secondary forests in the tropics provide timber and fire wood, maintain biodiversity and organic matter in the soil, and they are a source of medicinal plants. Currently, $40 \%$ of the tropical woodlands are secondary forests and each 
year 9 million hectares are cut (Brown \& Lugo, 1990). In the Caribbean the primeval forests have decreased during the four last centuries due to agriculture and urban development. The secondary forests resulting from human activities, are still much exploited and might disappear in the near future. On the island of Grande-Terre (Guadeloupe), secondary semi-evergreen forests cover only 2730 ha, i.e. $5 \%$ of the total surface. These forests contain few tree species, and several precious plant species, for example Calophyllum calaba, have disappeared. Huc (1985), Lugo et al. (1981) and Lugo (1992) have studied the vegetation in these forests, but no one has studied the dynamics of the soil organic matter.

The organic layers that form forest humus on the soil's surface are biologically very active, and decomposition is at its maximum there. The humus under temperate forests has been studied for over a century, and its three main forms, mull, moder and mor, are well established. In these forests, earthworms and white-rots (lignin-degrading fungi) produce mull in which litter decomposition is rapid and the organo-mineral horizon has a macrostructure. Mull humus profiles are distinct from profiles in which the activity of arthropods and enchytraeids dominate. In the latter, the moder and mor, litter decomposes slowly and organic and mineral materials are not mixed. A few investigations, such as BernhardReversat (1987) and Leroy et al. (1992), have studied the dynamics and function of humus forms in tropical forest ecosystems, and they are still poorly understood. The value of humus classification based on that in the temperate zone is still uncertain. 
Here we describe the structure of the humus forms under five tree species that produce litter with contrasting chemical qualities in two semi-evergreen woodlands in Guadeloupe, and we attempt to identify the biological processes influencing their development. Our hypothesis is that in these tropical forests, the quality of litter and soil fauna are the main factors determining the development of humus profiles, whereas microclimatic and edaphic properties are less important (Lavelle et al., 1993; Aerts, 1997). We examined the different components of humus horizons with a light microscope and described them in detail to understand their functioning. This method is one that we used and improved for the temperate zone (Ponge, 1990; Bernier \& Ponge, 1994; Peltier et al., 2001), where it helped us to discern the role of soil organisms in the transformation of organic matter and the formation of horizons. Here it is tested for the first time for the tropics.

\section{Materials and methods}

Site description

The study was carried out in two semi-evergreen woodlands, at Port-Louis, in North Grande-Terre (Guadeloupe). This region has a 6-month dry season (December to May). The annual rainfall is $1250 \mathrm{~mm}$ on average, and the mean annual temperature is $26^{\circ} \mathrm{C}$. During the dry season, the deciduous plant species loose their leaves and some of their twigs. The two plots have the same bedrock, a pure hard coral limestone from tertiary era (Pleistocene). A stratification exists within this thick $(200 \mathrm{~m})$ marine deposit. At the base (in contact with the volcanic 
shelf) are found softer sediments made of a mixing of calcareous shells, marine sands and volcanic debris. Above them was built the reef, now a wide plateau which has been inclinated and fractured by tectonic activity of the Caribbean plate.

The first site is a natural secondary forest relict of the primeval dry forest. It is one of the last such forests in Guadeloupe and is on a steep slope that may reach $45 \%$. This slope corresponds to the NW border of a fracture between two plateaux. The maximum altitude is $79 \mathrm{~m}$. The soil is a shallow calcareous Leptosol (FAO classification), which corresponds to a Rendzina in the CPCS classification (Duchaufour, 1997). It has a silt loam texture $(71 \%$ silt in the upper $10 \mathrm{~cm}$ and $28 \%$ silt at 30 to $40 \mathrm{~cm}$ depth). In the top $10 \mathrm{~cm}$, the soil is rich in organic matter $(21 \% \mathrm{C})$ and has a C:N ratio of 12.5 . The $\mathrm{pH}$ (in water) is 7.5 in the top $10 \mathrm{~cm}$ and 7.8 from 30 to $40 \mathrm{~cm}$ depth. The main canopy species are Pisonia subcordata L. and Bursera simaruba (L.) Sarg., two native deciduous tree species, which cover $32 \%$ and $24 \%$ of the total area, respectively (Loranger, 1999). We described the humus profiles and soil macrofauna under the canopy of these two species.

In this secondary forest we observed that the calcareous rock attacked by $\mathrm{HCl}$ disintegrated most easily on the lower slopes. For an unknown reason, probably due to differences in the nature of the original coral population (Gaiffe \& Bruckert, 1990), the underlying calcareous rock becomes increasingly more resistant to weathering, and the root systems of trees become progressively less developed when going upwards. For both tree species ( $B$. simaruba and $P$. subcordata), one humus profile was described on the lower, middle and upper slope (six humus profiles in total). Preliminary observations established that two 
distinct humus forms related to the two tree species occur in all three positions of the slope.

The second site is a 50-year-old plantation on a calcareous Vertisol on a plateau. This soil has a clay texture $(78 \%$ clay in the upper $10 \mathrm{~cm}$ and $76 \%$ clay from 30 to $40 \mathrm{~cm}$ depth). The top $10 \mathrm{~cm}$ contains $5.3 \% \mathrm{C}$ and has a $\mathrm{C}: \mathrm{N}$ ratio of 12. The $\mathrm{pH}$ (in water) is 7.7 in the top $10 \mathrm{~cm}$ and 8 from 30 to $40 \mathrm{~cm}$ depth. Originally, several species were planted for timber production by the National Office for Forests. Currently, the principal canopy species are Swietenia macrophylla King, Tabebuia heterophylla DC. Britton and B. simaruba, which cover $32 \%, 30 \%$ and $7 \%$ of the total area, respectively (Loranger, 1999). S. macrophylla is an exotic species, while $T$. heterophylla and $B$. simaruba are native. We have studied one humus profiles and the soil's macrofaunal communities under the canopy of these three deciduous species. All three species give rise to distinctive humus forms.

\section{Soil macrofauna}

We sampled the macrofauna in November 1997 (during the wet season) in the soil under the main tree species in both the secondary forest and the plantation, using the modified Tropical Soil Biology and Fertility method (Anderson \& Ingram, 1993). Ten individual trees of each species were randomly chosen in the two woodlands. Under the canopy of each tree, soil animals were collected and sorted by hand from a soil block $(30 \mathrm{~cm} \times 30 \mathrm{~cm} \times 30 \mathrm{~cm})$, which was dug out with a spade then 
sprinkled over a plastic sheet. Invertebrates were identified (a) at the species level for earthworms and millipedes and (b) as morphospecies for other groups.

Chemical leaf analyses

Freshly fallen leaves of the four canopy species, $P$. subcordata, $S$. macrophylla, $T$. heterophylla and B. simaruba, were collected from the forest floor. The leaves were air-dried and milled and the chemical composition determined.

The total nitrogen content was measured by the Kjeldahl method. Lignin and cellulose were analysed by sequential digestion of fibres (Van Soest, 1963). Samples were first extracted with neutral detergent. Lignocellulose (acid detergent fibre) was determined after extraction with acid detergent. Lignin (acid detergent lignin) was measured after hydrolysis with $72 \% \quad \mathrm{H}_{2} \mathrm{SO}_{4}$. The cellulose content corresponds to the difference between acid detergent fibre and acid detergent lignin. Total soluble phenols were extracted with $70 \%$ methanol then measured colorimetrically using the Folin-Ciocalteu method (Marigo, 1973). Tannins were measured with a colorimeter after precipitation with bovine serum albumin (Hagerman \& Butler, 1978).

Humus profiles

Humus profiles were sampled using the method described by Ponge (1984). A block of surface soil $5 \mathrm{~cm} \times 5 \mathrm{~cm} \times 15 \mathrm{~cm}(\mathrm{~L} \times \mathrm{w} \times \mathrm{h})$ was cut with a sharp knife, with as little disturbance as possible, and the litter and soil surrounding it were 
removed and the block excavated. Each humus block was separated in the field by eye into its obvious layers, without reference to any pre-conceived classification of horizons (Ponge 1999; Peltier et al., 2001). The thickness of each layer was measured. They were then classified into OL (entire leaves), OF (fragmented leaves), $\mathrm{OH}$ (holorganic faecal pellets) and $\mathrm{A}$ (organo-mineral material) horizons, according to the classification of Brêthes et al. (1995), and their subdivision numbered from the top downwards, $\mathrm{OL}_{1,2, \ldots}, \mathrm{OF}_{1,2, \ldots}, \mathrm{OH}_{1,2, \ldots}$ and $\mathrm{A}_{1,2, \ldots}$ etc. Fifty six horizons were sampled in the secondary forest and 21 in the plantation. All 77 layers were immediately fixed in $95 \%$ ethanol and transported to the laboratory.

The composition of each humus layer was analysed under a dissecting microscope at $\times 40$ magnification. In all, 45 types of material were recognized, 42 in the secondary forest and 28 in the plantation (Table 1). Most of the materials were plant litter at different stages of decomposition or comminution by soil fauna. The volume ratio of each identified type was measured using the count point method (Jongerius, 1963; Bal, 1970; Bernier \& Ponge, 1994). The 45 types were grouped into seven main categories which were used to build simplified humus diagrams (Figures 1,2 and 5). This micromorphological method enables the exploration of a greater volume of soil than the thin section method, but the pore patterns cannot be evaluated.

Millipede faecal pellets and organo-mineral material

After components of humus horizons had been identified and counted under the dissecting microscope, aggregates were inspected at the magnification $\times 400$, 
using the method described by Bernier \& Ponge (1994), to determine their internal composition. They were broken down gently in a drop of methyl-blue-lacto-phenol then observed under a phase contrast microscope. Three samples each of three categories (faecal pellets of millipedes, fresh earthworm casts, and organo-mineral material) were analysed. Eleven types of material were recognized under the microscope: plant fragments, mineral particles, free amorphous organic matter, amorphous organic matter bound to minerals, coal, pollen, plant epidermal cells, fungal hyphae, bacteria, earthworm cells and miscellaneous. The volume ratio of each identified component was again estimated using the count-point method.

\section{Results}

Soil macrofauna

Fifty-one species or morphospecies of soil macrofauna were found in the two forests (Table 2), 39 in the secondary forest and 28 in the plantation. The two sites had 16 morphospecies in common.

Millipedes, insect larvae, ants and termites were the most abundant arthropod groups. Millipedes (29 to 206 individuals $\mathrm{m}^{-2}$ ) dominated the soil macrofauna. The main millipede species was Anadenobolus monilicornis, which is known to inhabit dry soils (Mauriès, 1980).

Two earthworm species were found: Dichogaster sp., a small epigeic species, and Polypheretima elongata, an endoanecic species. Dichogaster sp. 
was present in both sites (Table 2). P. elongata was found only in the Vertisol under the plantation.

Litter chemical analyses

Chemical analyses (Table 3) showed that freshly fallen leaves of $B$. simaruba and S. macrophylla had the biggest content of phenols and tannins. Due to their large lignin content, these leaves had the smallest cellulose content. The leaves of $P$. subcordata had more nitrogen (2.5\%) than those of all other species.

Description and development of humus profiles: the secondary forest

In the secondary forest two different humus forms were observed. The first (Fig. 1) is characterized by a $1.5 \mathrm{~cm}$ thick $\mathrm{OH}$ horizon, which has a granular structure and consists of faecal pellets of millipedes. The organo-mineral A horizon below has a crumb structure. This humus form resembles a calcareous Amphimull as defined by Brêthes et al. (1995), but there is evidence of much millipede activity. This humus form is typical of the middle slope plot under $P$. subcordata.

The second humus form, which has a $7 \mathrm{~cm}$ thick root mat, or $\mathrm{OF}_{\mathrm{Rh}}$ horizon (Loranger, 2001), can be classified as a Dysmull (Brêthes et al., 1995). A similar root horizon has also been observed in tropical rain forests elsewhere (Leroy et al., 1992). The Dysmull with its thick root mat is typical of the upper slope plot under B. simaruba (Fig. 2). In these profiles, the litter is usually transformed mainly 
by epigeic arthropods, but we found only a few animal faeces in the organic layers. The organo-mineral A horizon has a crumb structure.

The influence of site and tree species on the composition of horizons was analysed by grouping the types of materials into broader categories, the percentage volume of which was calculated for the layer in which they were most abundant. The proportions of fragmented leaves (at 4-6 cm depth), organo-mineral aggregates (at 4-6 cm depth) and roots (at 8-10 cm depth) varied greatly between plots and trees (Table 4). Between 4 and $6 \mathrm{~cm}$ depth there were more fragmented leaves and fewer organo-mineral aggregates in the profiles on the upper slope than those on the two lower plots, indicating that litter was less rapidly incorporated on the upper slope than elsewhere. Between 8 and $10 \mathrm{~cm}$ depth, there were more roots under $B$. simaruba than under $P$. subcordata, showing that B. simaruba tends to develop of a root mat ( $\mathrm{OF}_{\mathrm{Rh}}$ horizon).

Description and development of humus profiles: the plantation

In the plantation, humus profiles are similar for all three tree species in spite of differences in litter quality (Table 3). The OL horizon is discontinuous and comprises intact leaves, twigs, and wood. This horizon is 0.2 to $2 \mathrm{~cm}$ thick. OF and $\mathrm{OH}$ horizons are absent, and there are few millipede faeces in spite of the abundance of these animals (Table 2). The transition to the underlying organomineral A horizon, which has a crumb structure, is sharp. The humus form (Figure 3) is an Eumull (Brêthes et al., 1995). 
Microscopic assessment of organic and organo-mineral aggregates

The millipede organic faeces contain more plant fragments than all other aggregates (Table 5). For example they contain six times more $(93.4 \pm 1.8 \%)$ than the millipede organo-mineral faeces (16.4 $\pm 1.6 \%)$. Organo-mineral earthworm casts in the plantation were richer in plant fragments than other (non-animal) organo-mineral aggregates. In particular they contain twice as many plant fragments $(62.3 \pm 14.6 \%)$ as organo-mineral aggregates of non-animal origin $(27.1 \pm 11.9 \%)$. Amorphous organic matter bound to minerals was more abundant in earthworm casts $(16.0 \pm 0.3 \%)$ than in other organo-mineral aggregates ( $7.4 \pm 3.0 \%$ in the plantation, $8.8 \pm 1.9 \%$ in the secondary forest).

\section{Discussion}

In the secondary forest we found an epigeic macrofaunal community dominated by millipedes. These animals ingest fresh organic matter and deposit their faecal pellets at the soil surface. The endoanecic earthworm $P$. elongata was absent, probably because this species cannot tolerate dehydration and needs to aestivate when the soil dries out, which is impossible in the shallow Leptosol.

Millipedes are especially abundant under the canopy of $P$. subcordata (136 individuals $\mathrm{m}^{-2}$ ), probably because the foliage of this tree species is rich in nitrogen (2.5\%). As a result, millipedes produce abundant faecal pellets which accumulate to form a thick superficial $\mathrm{OH}$ horizon. This is possible only in the absence of endoanecic earthworms that would ingest and incorporate them into an A horizon. 
Bursera simaruba belongs to a family of trees known for their disinfecting properties (Stehlé, 1943). Its leaves contain much lignin ( $23 \%$ of dry matter) and phenols (10\% of dry matter) and decompose slowly (Loranger, 1999). Both of these factors may slow the biodegradation of its litter. The $\mathrm{OF}_{\mathrm{Rh}}$ horizon is best developed in the plot on the upper slope where the parent material was a hard and pure calcareous rock. This weakly weathered bedrock might favour the development of a thick superficial root mat because roots cannot penetrate.

In the plantation, we found two macrofaunal communities, a) an epigeic (litter-dwelling) one dominated by millipedes and an endogeic (soil-dwelling) one dominated by the endoanecic earthworm $P$. elongata which feeds on organomineral material and probably also on faeces of the former group. The mixing role of this earthworm favours the formation of clay/humus complexes (Bouché et al., 1983; Bernier, 1998), which is shown by the abundance of organic matter bound to minerals (Table 5). Their activity maintains a macroporous crumb structure (Alegre et al., 1996; Blanchart et al., 1997) and forms an Eumull humus profile, whatever the tree species. They also bury litter under their casts thereby accelerating the incorporation of litter into the soil. The Vertisol has a large water capacity, providing suitable conditions for the establishment of $P$. elongata. When worm activity is lesser, as observed in the plantation under $B$. simaruba, the thickness of the OL layer increases. Despite the abundance of millipedes, only earthworm activity is expressed in the composition of the humus profile. 
The organo-mineral aggregates in the plantation soil probably result from a combination of earthworm activity (rounded aggregates) and shrinking and swelling of smectites (polyhedral aggregates). In contrast, in the humus profiles of the secondary forest, the organo-mineral horizon has a macrostructure, the origin of which is still poorly understood. The organo-mineral aggregates of the secondary forest could be derived by the precipitation of colloidal organic matter by clay minerals (Chenu, 1989), followed by seasonal shrinking and swelling of smectites. It is possible, however, that in the sites we studied some millipedes might have ingested humified organic matter and deposited organo-mineral faeces in their galleries (Loranger, 1999), so that we can find old millipede organo-mineral faeces bound together in the A horizon. However, these millipedes cannot create large crumb structures as earthworms do.

In tropical semi-evergreen forests, as in temperate forests, the activity of endoanecic earthworms gives mull humus profiles, whatever the quality of the litter. These worms mix mineral and organic material, homogenize the upper the soil profile and help to maintain porosity. Where endoanecic earthworms are absent, as in the secondary forest, humus forms are more varied and depend on parent rock, litter quality, and millipede activity.

We conclude that soil fauna and litter quality are key factors in the development of humus profiles in tropical semi-evergreen forests and that parent rock and edaphic factors can be equally important in some calcareous soils. We believe, however, that our conclusions may not apply to non calcareous tropical soils. 


\section{Acknowledgements}

We thank Professor Paul Leadley (Université d'Orsay, France) and the deputy editor J.M. Hodgson (Rothamsted, UK) for revising our English language, and Professor Jean-Paul Mauriès (Muséum National d'Histoire Naturelle, Paris) for identifying the millipedes at the species level.

\section{References}

Aerts, R. 1997. Climate, leaf litter chemistry and leaf litter decomposition in terrestrial ecosystems: a triangular relationship. Oikos, 79, 439-449.

Alegre, J.C., Pashanasi, B. \& Lavelle, P. 1996. Dynamics of soil physical properties in Amazonian agroecosystems inoculated with earthworms. Soil Science Society of America Journal, 60, 1522-1529.

Anderson, J.M. \& Ingram, J.S.I. 1993. Tropical Soil Biology and Fertility: a Handbook of Methods, $2^{\text {nd }}$ ed. CAB International, Wallingford.

Bal, L. 1970. Morphological investigation in two moder-humus profiles and the role of the soil fauna in their genesis. Geoderma, 4, 5-36.

Bernhard-Reversat, F. 1987. Litter incorporation to soil organic matter in natural and planted tree stands in Senegal. Pedobiologia, 30, 401-417. 
Bernier, N. 1998. Earthworm feeding activity and development of the humus profile. Biology and Fertility of Soils, 26, 215-223.

Bernier, N. \& Ponge, J.F. 1994. Humus form dynamics during the sylvogenetic cycle in a mountain spruce forest. Soil Biology and Biochemistry, 26, 183-220.

Blanchart, E., Lavelle, P., Braudeau, E., Le Bissonais, Y. \& Valentin, C. 1997. Regulation of soil structure by geophagous earthworm activities in humid savannas of Cote d'Ivoire. Soil Biology and Biochemistry, 29, 431-439.

Bouché, M.B., Rafidison, Z. \& Toutain, F. 1983. Étude de l'alimentation et du brassage pédo-intestinal du lombricien Nicodrilus velox (Annelida, Lumbricidae) par l'analyse élémentaire. Revue d'Écologie et de Biologie du Sol, 20, 49-75.

Brêthes, A., Brun, J.J., Jabiol, B., Ponge, J.F. \& Toutain, F. 1995. Classification of forest humus forms: a French proposal. Annales des Sciences Forestières, 52, $535-546$.

Brown, S. \& Lugo, A.E. 1990. Tropical secondary forests. Journal of Tropical Ecology, 6, 1-32.

Chenu, C. 1989. Influence of a fungal polysaccharide, scleroglucan, on clay microstructures. Soil Biology and Biochemistry, 21, 299-305. 
Duchaufour, P. 1997. Abrégé de Pédologie. Sol, Végétation, Environnement. Masson, Paris.

Gaiffe, M. \& Bruckert, S. 1990. Origine paléoécologique de l'aptitude des calcaires jurassiques à la fracturation. Conséquences tectoniques, pédogénétiques et écologiques. Bulletin de la Société Neufchâteloise des Sciences Naturelles, 113, 191-206.

Hagerman, A.E. \& Butler, L.G. 1978. Protein precipitation method for the quantitative determination of tannins. Journal of Agriculture and Food Chemistry, 26, 809-812.

Huc, R. 1985. Premiers résultats expérimentaux sur le comportement de Tabebuia heterophylla (D.C.) Britton et de Hymenaea courbaril L., vis-à-vis de la sécheresse. Annales des Sciences Forestières, 42, 201-244.

Jongerius, A. 1963. Optic-volumetric measurements on some humus forms. In: Soil Organisms (eds J. Doeksen \& J. Van Der Drift), pp. 137-148. North Holland Publishing Company, Amsterdam.

Lavelle, P., Blanchart, E., Martin, A., Martin, S., Spain, A., Toutain, F., Barois, I. \& Schaefer, R. 1993. A hierarchical model for decomposition in terrestrial ecosystems: application to soils of the humid tropics. Biotropica, 25, 130-150. 
Leroy, C., Toutain, F. \& Lavelle, P. 1992. Variations des caractéristiques de l'humus forestier d'un sol ferrallitique (Guyane) selon l'essence arborée considérée. Résultats préliminaires. Cahiers de l'ORSTOM, Série Pédologie, 27, 37-48.

Loranger, G. 1999. Déterminants de la Décomposition de la Litière dans une Forêt semi-décidue de la Guadeloupe. Thèse de doctorat, Université Paris 6.

Loranger, G. 2001. Formes d'humus originales dans une forêt tropicale semidécidue de la Guadeloupe. Comptes Rendus de l'Académie des Sciences de Paris, Série III, Sciences de la Vie, 324, 725-732.

Lugo, A.E. 1992. Comparison of tropical tree plantation with secondary forest of similar age. Ecological Monographs, 62, 1-41.

Lugo, A.E., Schmidt, R. \& Brown, S. 1981. Tropical forests in the Caribbean. Ambio, 10, 318-324.

Marigo, G. 1973. Sur une méthode de fractionnement et d'estimation des composés phénoliques chez les végétaux. Analusis, 2, 106-110.

Mauriès, J.P. 1980. Diplopodes Chilognates de la Guadeloupe et ses dépendances. Bulletin du Muséum National d'Histoire Naturelle, 2, 1059-1111. 
Peltier, A., Ponge, J.F., Jordana, R. \& Ariño, A. 2001. Humus forms in Mediterranean scrublands with aleppo pine. Soil Science Society of America Journal, 65, 884-896.

Ponge, J.F. 1984. Etude écologique d'un humus forestier par l'observation d'un petit volume, premiers résultats. I.- La couche $L_{1}$ d'un moder sous pin sylvestre. Revue d'Ecologie et de Biologie du Sol, 21, 161-187.

Ponge, J.F. 1990. Ecological study of a forest humus by observing a small volume. I. Penetration of pine litter by mycorrhizal fungi. European Journal of Forest Pathology, 20, 290-303.

Ponge, J.F. 1999. Horizons and humus forms in beech forests of the Belgian Ardennes. Soil Science Society of America Journal, 63, 1888-1901.

Stehlé, H. 1943. Classification des arbres à latex et à sécrétion de gomme, résines et matières colorantes des Antilles françaises. The Caribbean Forester, $4,112-123$.

Van Soest, P.J. 1963. Use of detergents in the analysis of fibrous feeds. II. A rapid method for determination of fibre and lignin. Journal of the Association of Official Analytical Chemists, 46, 829-835. 
Table 1 Types of humus material in two semi-evergreen forests in Guadeloupe

\begin{tabular}{|c|c|c|}
\hline Categories & $\begin{array}{c}\text { Secondary } \\
\text { forest }\end{array}$ & $\begin{array}{c}\text { Plantatio } \\
\mathbf{n}\end{array}$ \\
\hline Entire brown leaves & $x$ & $x$ \\
\hline Entire bleached leaves & $x$ & $x$ \\
\hline Brown leaf fragments skeletonized by mesofauna & $x$ & \\
\hline Brown leaf fragments cut out by macrofauna & $x$ & $x$ \\
\hline Brown leaf fragments cut out by macrofauna and browsed by mesofauna & $\times$ & \\
\hline Bleached leaf fragments cut out by macrofauna & $x$ & $x$ \\
\hline Entire little twigs (diameter $<2 \mathrm{~mm}$ ) & $\times$ & $x$ \\
\hline Little twigs (diameter $<2 \mathrm{~mm}$ ) decayed and tunnelled by fauna & $x$ & $x$ \\
\hline Entire large twigs (diameter > $2 \mathrm{~mm}$ ) & $x$ & $x$ \\
\hline Large twigs (diameter $>2 \mathrm{~mm}$ ) decayed by fauna & $x$ & $x$ \\
\hline Intact petioles & $\times$ & \\
\hline Petioles decayed and browsed by fauna & $x$ & \\
\hline Intact wood fragments & $x$ & $x$ \\
\hline Decayed wood fragments & $x$ & $x$ \\
\hline Bark fragments & $x$ & $x$ \\
\hline Living fine roots (diameter $<2 \mathrm{~mm}$ ), intact & $x$ & $x$ \\
\hline Living fine roots (diameter $<2 \mathrm{~mm}$ ), browsed by fauna & $x$ & $x$ \\
\hline Dead fine roots (diameter $<2 \mathrm{~mm}$ ) & $\times$ & $x$ \\
\hline Living roots of intermediate diameter $(6 \mathrm{~mm}>$ diameter $>2 \mathrm{~mm})$, intact & $x$ & $x$ \\
\hline Living roots of intermediate diameter $(6 \mathrm{~mm}>$ diameter $>2 \mathrm{~mm})$, browsed by fauna & $x$ & $x$ \\
\hline Dead roots of intermediate diameter $(6 \mathrm{~mm}>$ diameter $>2 \mathrm{~mm})$ & $x$ & $x$ \\
\hline Living large roots (diameter $>6 \mathrm{~mm}$ ), intact & $x$ & $x$ \\
\hline Living large roots (diameter $>6 \mathrm{~mm}$ ), browsed by fauna & $\times$ & $x$ \\
\hline Dead mycorrhizae & $x$ & \\
\hline Rhizomorphs & $x$ & $x$ \\
\hline Intact walls of dry fruits & $x$ & \\
\hline Intact dry fruits & $x$ & \\
\hline Decayed dry fruits & $x$ & \\
\hline Intact fleshy fruits & $x$ & \\
\hline Decayed fleshy fruits & $x$ & \\
\hline Undetermined intact seeds & $x$ & \\
\hline Organic epigeic earthworm faeces & $x$ & \\
\hline Organic millipede faeces & $x$ & $x$ \\
\hline Bleached organic millipede faeces & $\times$ & \\
\hline Organic faeces of mesofauna & $x$ & \\
\hline Organo-mineral polyhedric structures & $\times$ & \\
\hline Organo-mineral polyhedric aggregates & & $x$ \\
\hline Earthworm casts & & $x$ \\
\hline Organo-mineral millipede faeces & $x$ & \\
\hline Limestone & $x$ & $x$ \\
\hline Snail shells & $x$ & $x$ \\
\hline Fragments of arthropod cuticles & $x$ & \\
\hline Millipedes & $x$ & $x$ \\
\hline Scarabid larvae & $x$ & $x$ \\
\hline Earthworms & & $x$ \\
\hline
\end{tabular}


Table 2 Densities of soil macrofauna (mean numbers of individuals per square metre with standard errors in brackets) under four tree species in two secondary semi-evergreen forests in Guadeloupe.

Only Diplopoda (millipede) and Oligochaeta (earthworm) species are included

\begin{tabular}{lllll}
$\begin{array}{l}\text { Swietenia } \\
\text { macrophylla } \\
\text { (plantation) }\end{array}$ & $\begin{array}{l}\text { Tabebuia } \\
\text { heterophylla } \\
\text { (plantation) }\end{array}$ & $\begin{array}{l}\text { Bursera } \\
\text { simaruba } \\
\text { (plantation) }\end{array}$ & $\begin{array}{l}\text { Pisonia } \\
\text { subcordata } \\
\text { (secondary } \\
\text { forest) }\end{array}$ & $\begin{array}{l}\text { Bursera } \\
\text { simaruba } \\
\text { (secondary } \\
\text { forest) }\end{array}$ \\
\hline
\end{tabular}

Diplopoda (7 species)

Orthomorpha coarctata

$0 \quad 0$

$1.6(1.7) \quad 1.6(1.7)$

Anadenobolus monilicornis

$96.0(26.7) \quad 123.2(30.8) \quad 46.4(19.1)$

$105.6(50.6) \quad 25.6(11.3)$

Trigoniulus corallinus 0

$0 \quad 1.6(1.7)$

$1.6(1.7)$

$1.6(1.7)$

Spilostrophus naresi

$33.6(28.2)$

24 (13.1)

$51.2(34.1)$

$19.2(14.4) \quad 0$

Epinannolene pittieri

$4.8(3.6)$

$59.2(30.0)$

4.8 (2.6)

0

0

Pseudospirobolellus avernus

$3.2(2.3)$

0

$9.6(5.3)$

$6.4(4.5) \quad 0$

Siphonophora filiformis

0

0

0

$1.6(1.7) \quad 0$

Oligoaeta (2 species)

Dichogaster sp.

$3.2(3.4)$

$4.8(2.6) \quad 9.6(4.5)$

0

4.8 (3.6)

Polypheretima elongata

$8.0(3.8)$

$6.4(3.7)$

$1.6(1.7)$

0

0

Chilopoda (2 morphospecies)

$9.6(5.2)$

$4.8(2.6) \quad 3.2(2.3)$

4.8 (3.9)

$9.6(7.1)$

Coleoptera (5 morphospecies)

8.0 (3.8)

$1.6(1.7)$

$3.2(3.4)$

$6.4(4.3)$

Formicida (11 morphospecies)

$6.4(6.8)$

$4.8(5.1)$

$12.8(11.7)$

$41.6(35.4) \quad 35.2(20)$

Isoptera (1 morphospecies)

$57.6(60.7)$

17.6 (11.9)

$9.6(8.4)$

$1.6(1.7)$

0

Insect larvae (10 morphospecies)

$9.6(5.2)$

$94.4(27.2) \quad 80.0(57.0)$

$9.6(9)$

$19.2(9.4)$

Isopoda (3 morphospecies)

$1.6(1.7)$

$28.8(8.3)$

$19.2(13.7)$

$40.0(20.2)$

$9.6(6)$

Dermaptera (1 morphospecies)

0

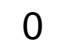

0

$3.2(2.3)$

$9.6(5.2)$

Blattodea (3 morphospecies)

0

0

$3.2(2.3)$

$4.8(5.1)$

$9.6(6.8)$

Araneidae (3 morphospecies)

0

0

0

$3.2(3.4)$

$3.2(3.4)$

Heteroptera (1 morphospecies)

0

0

0

$1.6(1.7)$

Homoptera (1 morphospecies)

0

$0 \quad 0$

Orthoptera (1 morphospecies)

$3.2(2.3)$

$1.6(1.7)$

$4.8(5.1)$

0

0

242 (151)

373 (139)

255 (167)

0

0

TOTAL

(151)

373 (139) 255 (167)

253 (164)

$138(82)$ 
Table 3 Chemical composition (mean percent of dry matter with standard error) of leaves of the four selected tree species. Values are means of three replicates

\begin{tabular}{lcccc}
\hline & Pisonia & Swietenia & Tabebuia & Bursera \\
& subcordata & macrophylla & heterophylla & simaruba \\
\hline Total nitrogen & $2.5(0.1)$ & $1.1(0.1)$ & $0.9(0.1)$ & $1.1(0.1)$ \\
Cellulose & $19.2(0.6)$ & $19.8(4.1)$ & $32.1(2.3)$ & $20.9(0.4)$ \\
Lignin & $29.5(15.1)$ & $29.1(10)$ & $12.0(2.1)$ & $22.8(9.6)$ \\
Soluble phenols & $6.7(0.6)$ & $12.7(0.6)$ & $4.5(2.3)$ & $10.0(1.0)$ \\
Tannins & $1.8(0.8)$ & $2.9(0.6)$ & $0.3(0.1)$ & $3.3(0.7)$ \\
\hline
\end{tabular}


Table 4 Secondary forest. Influence of position on the slope and tree species on bulk types of material identified under the dissecting microscope. Mean volume of material type is indicated in percent of the total matrix with standard error between brackets

\begin{tabular}{llll}
\hline & $\begin{array}{l}\text { Fragmented } \\
\text { leaves } \\
4-6 \mathrm{~cm}\end{array}$ & $\begin{array}{l}\text { Organo-mineral } \\
\text { aggregates } \\
4-6 \mathrm{~cm}\end{array}$ & $\begin{array}{l}\text { Roots } \\
8-10 \mathrm{~cm}\end{array}$ \\
\hline Lower slope $(\mathrm{n}=2)$ & $2.0(0.3)$ & $53.9(3.8)$ & $29.2(9.0)$ \\
Middle slope $(\mathrm{n}=2)$ & $1.8(0.1)$ & $33.3(9.1)$ & $22.9(4.0)$ \\
Upper slope $(\mathrm{n}=2)$ & $63.1(0.1)$ & $0.0(0.04)$ & $26.1(3.6)$ \\
\hline Bursera simaruba $(\mathrm{n}=3)$ & $15.1(0.4)$ & $17.9(7.1)$ & $34.6(5.5)$ \\
Pisonia subcordata $(\mathrm{n}=3)$ & $5.9(0.2)$ & $23.3(8.2)$ & $11.0(4.3)$ \\
\hline
\end{tabular}


Table 5 Aggregate components identified under the phase contrast microscope. Comparisons between five types of aggregates with three replicates each. Mean volume of each component is indicated in percent with standard error between brackets

$\begin{array}{lll}\begin{array}{l}\text { Plant } \\ \text { fragments }\end{array} & \begin{array}{l}\text { Free amorphous } \\ \text { organic matter }\end{array} & \begin{array}{l}\text { Amorphous organic Mineral } \\ \text { matter bound to material } \\ \text { minerals }\end{array}\end{array}$

Millipede organic faeces (secondary forest)

$93.4(1.8) \quad 5.3(0.9) \quad 0$

$0.1(0.1)$

Millipede organomineral faeces $16.4(1.6) \quad 69.2(5.5)$ $10.7(3.9)$ $3.5(0.6)$ (secondary forest)

Earthworm casts, (plantation)

Organo-mineral aggregates $27.1(11.9) \quad 45.4(20.3)$ (plantation)

Organo-mineral aggregates (secondary forest) 


\section{Figure captions}

Figure 1 Composition of Amphimull with marked millipede activity, from the secondary forest (middle slope plot), under Pisonia subcordata

Figure 2 Composition of Dysmull with a thick root mat from the secondary forest (upper slope plot), under Bursera simaruba

Figure 3 Composition of Eumull from the plantation, under Swietenia macrophylla 


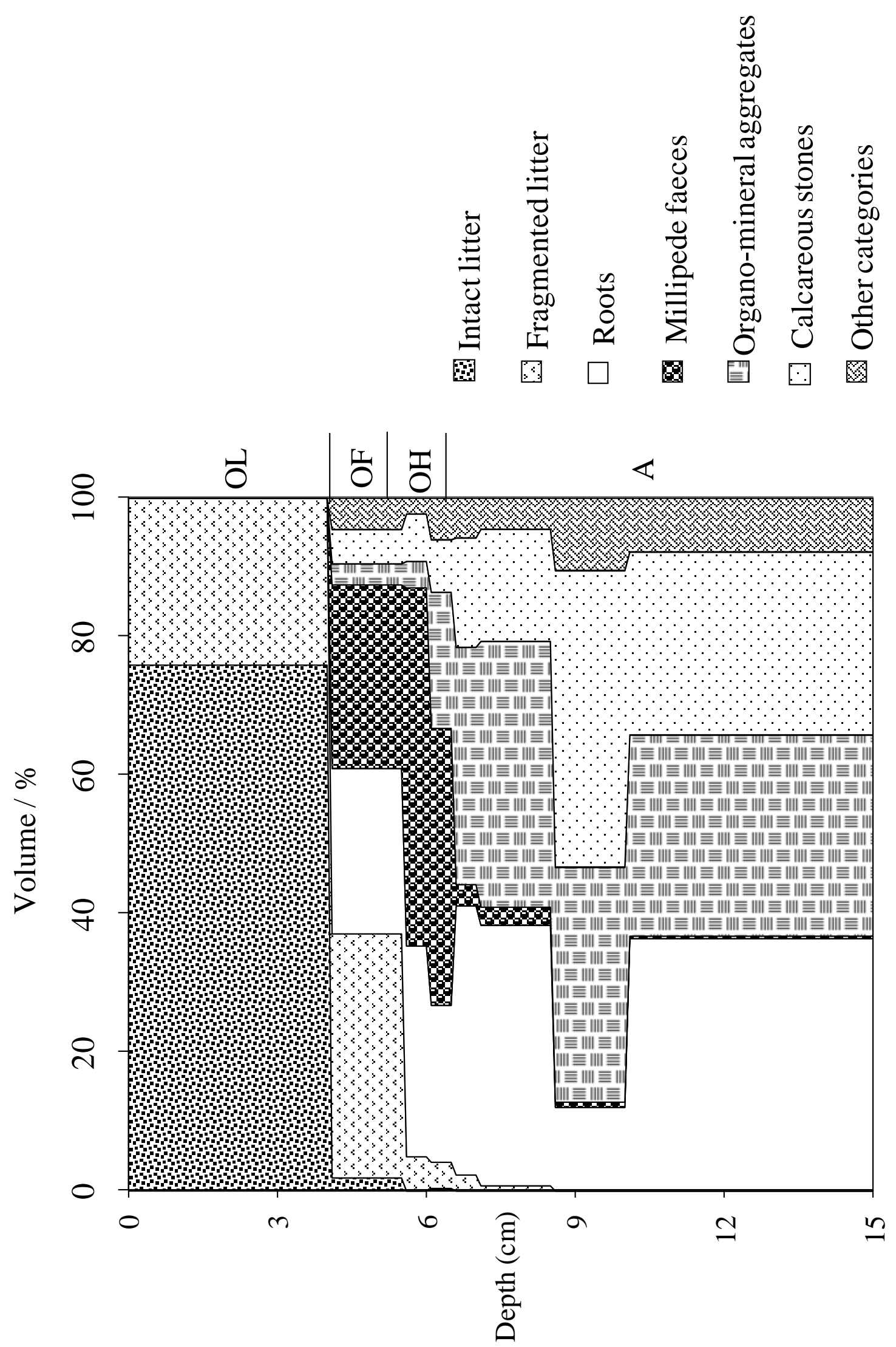

Fig. 1 


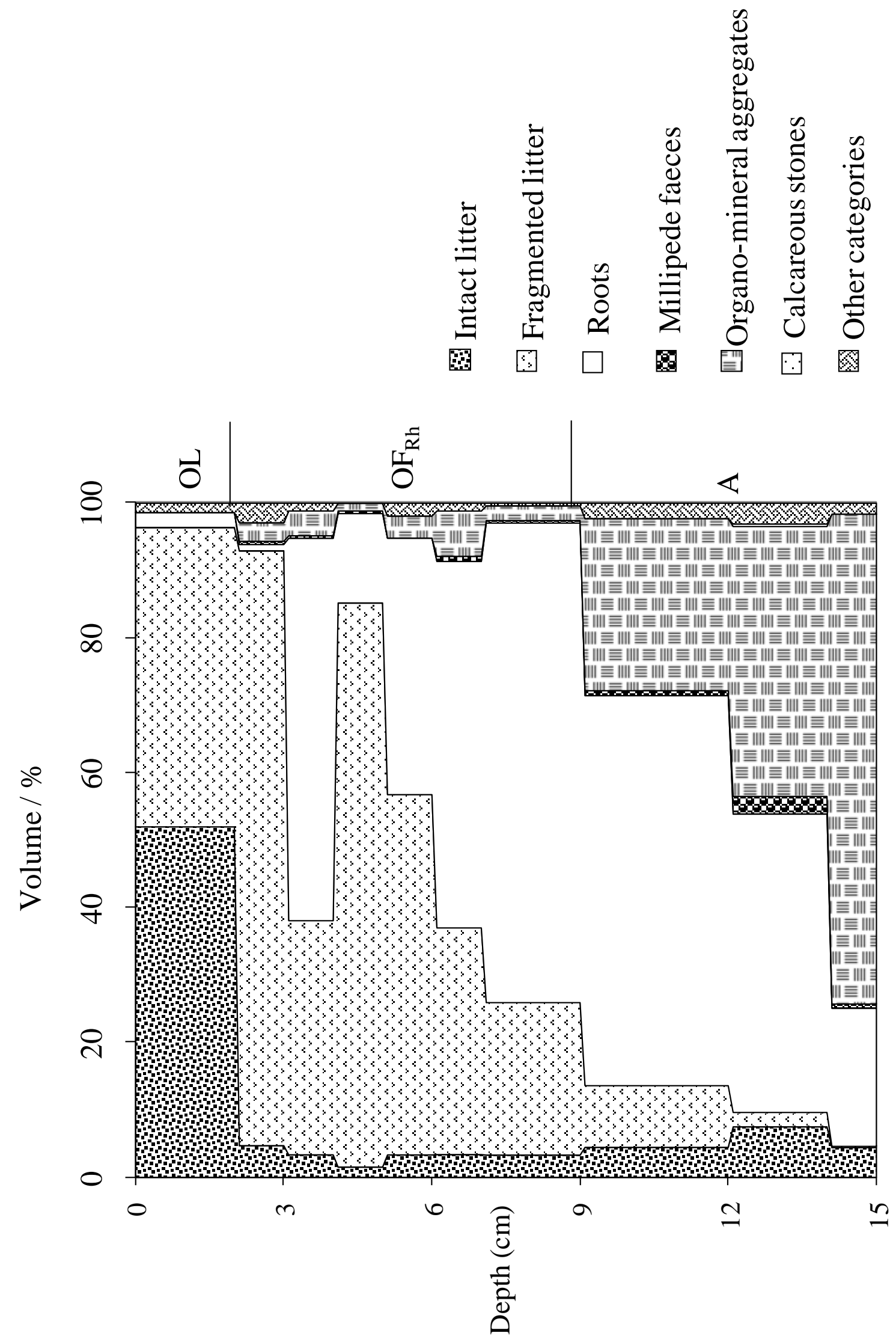

Fig. 2 

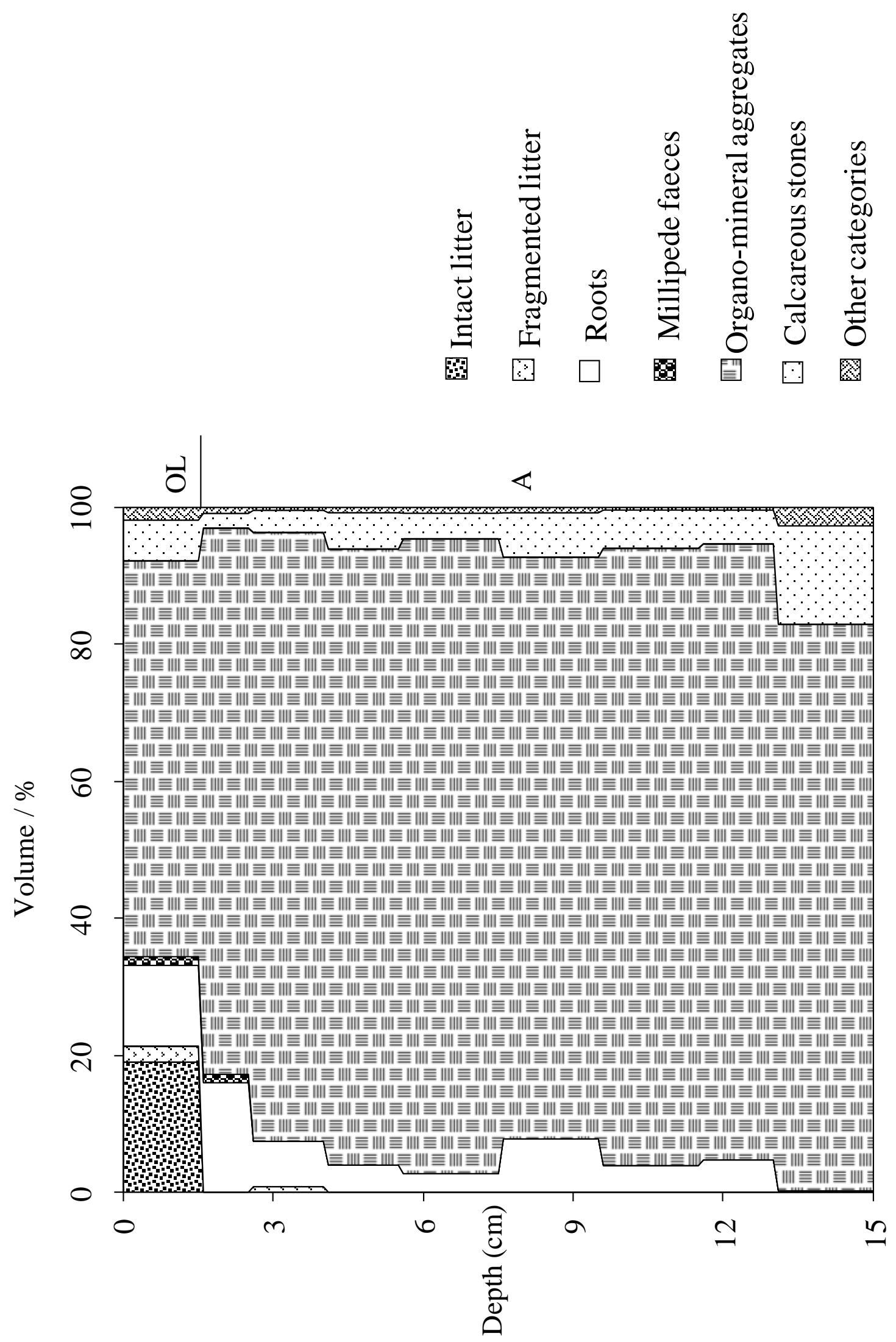

Fig. 3 